\title{
DUKUNGAN KELUARGA DAN DEPRESI PADA PENDERITA HIV/AIDS DI YOGYAKARTA
}

\author{
Panji Andhika Pratama \\ Rr. Indahria Sulistyarini \\ Fakultas Psikologi dan Ilmu Sosial Budaya Universitas Islam Indonesia
Email : indahriasulistyarini@yahoo.co.id
}

\begin{abstract}
The aim of this study is to find out the relationship between family effect on the intention of depression on HIVIAIDS victim. The hypothesis of this research is there is a negative relationship between family support and of depression on HIVIAIDS victim. The subject of this research is 50 ODHA in Yogyakarta, 2 men and 48 woman. The scale for this research conducted by the reseacher based on the House aspect of family support (Smet, 1994), and adaptation of Beck scale is used to measure the depression aspect (1987), which is BDI II (Beck Depression Inventory II). Data analysist method on this research is using Spearman's non parametic corelation. The analysist shows $r=-0.434$ and $p=0.001(p<0.05)$. The data shows the higher the family support, the lower of depression on the HIVIAIDS victim. And in reverse, the lower the family support, the higher of depression on the HIVIAIDS victim. Based on this research, we can see that family support contribute $18.9 \%$ in reducing the intention of depression on HIV/AIDS victim.
\end{abstract}

\section{Key Words : Family Intention, Depression}

Manusia merupakan makhluk paling sempurna yang diciptakan oleh Allah SWT. Manusia mengalami perkembangan yang sangat pesat untuk menjadi organisme yang lengkap. Manusia berusaha mewujudkan keinginan-keinginan dalam hidup yang mendapatkan dukungan dari keluarganya dan orang-orang terdekatnya untuk mencapai tujuannya. Begitu juga dengan Orang Dengan HIV/AIDS (ODHA) dalam menjalani hidupnya. Acruired Immune Deficiensy Syndrome atau yang lebih dikenal dengan istilah AIDS merupakan penyakit yang relatif baru yang ditandai dengan adanya kelainan yang komplek dalam sistem pertahanan selular tubuh dan menyebabkan korban menjadi sangat peka terhadap mikroorganisme oportunistik. Penyakit AIDS disebabkan oleh Human Immunodeficiency Virus atau disingkat dengan HIV. Penyakit ini merupakan penyakit menular seksual, yang pada mulanya dialami oleh kelompok kaum homoseksual.

Penyakit ini muncul karena hubungan seksual (sodomi) yang dilakukan oleh komunitas kaum homoseksual. Cherman dan Sinoussi (Tjokro, dkk, 1992) menyatakan perkembangan kasus AIDS di dunia, makin lama makin banyak dilaporkan dan merupakan persoalan kesehatan masyarakat di berbagai Negara. Penderita AIDS di seluruh dunia mencapai lebih dari 12.000 orang di antaranya 10.000 kasus di Amerika Serikat, 400 kasus di Prancis dan sisanya di negara Eropa lainnya, Amerika Latin, dan Afrika (Wijayanto, 2009).

Kasus AIDS pertama di Indonesia dilaporkan di Bali pada bulan April tahun 1987, yaitu seorang wistawan Belanda yang meninggal di RSUP Sanglah Denpasar. Pada awalnya penyebaran HIV/AIDS di 
Indonesai terjadi pada pekerja seks komersial (PSK) beserta pelanggannya. Setelah itu mulai terjadi penularan ke ibu-ibu rumah tangga yang tertular dari pasangannya dan berlanjut ke bayi-bayi yang lahir dari ibu yang positif HIV (Pusat Data dan Informasi Departemen Kesehatan RI, 2006).

Sementara itu di daerah Provinsi DIY dari tahun 1993-2010 data yang didapat peneliti menurut distribusi frekuensi jenis kelamin laki-laki terdapat 845 kasus sedangkan perempuan 380 dan 63 kasus tidak diketahui, dari distribusi frekuensi ODHA yang hidup 1.065 sedangkan 172 yang meninggal, dari data keseluruhan di Provinsi DIY dari tahun 1993-2010 terdapat 1288 kasus HIV/AIDS (Departemen Kesehatan Provisinsi DIY, Senin 18 April 2011). Hal ini juga diperkuat dengan pernyataan seorang konselor di RS Sardjito yang menangani kasus HIV/AIDS tentang kecenderungan depresi yang dialami ODHA, biasanya ciri-ciri ODHA yang depresi itu menarik diri, tidak mau keluar rumah, kebanyakan konfliknya dengan keluarga sehingga ODHA di lingkungan sosial mereka tertekan dan kasus ODHA ingin bunuh diri juga ada, sampai ada dirujuk ke RS Jiwa, itu adalah ODHA yang mengalami depresi berat. Ada juga ODHA yang sudah terbuka terhadap penyakit yang dideritanya kepada keluarganya sehingga kebanyakan ODHA dengan kasus seperti ini sudah bisa berterus terang terhadap keluarganya kecenderungan depresinya berkurang, tapi ODHA itu diberi hak untuk merahasiakan penyakitnya untuk dirinya sendiri atau keluarganya (Wawancara, 8 April 2011).

Infeksi HIV dan gangguan psikiatrik hubungan yang kompleks, menjadi terinfeksi HIV akan menyebabkan gangguan psikiatrik, sebagai konsekuensi psikologis dari infeksi atau karena efek dari virus HIV dalam otak. Perjalanan penyakit AIDS yang progresif dan berakhir dengan kematian, serta penyebaran yang cepat, adanya stigma dan diskriminasi terhadap penderita dapat menimbulkan keadaan stres dan gangguan psikiatrik pada penderita tersebut. Peneliti menujukkan bahwa prevalensi gangguan psikiatrik pada orang yang hidup dengan HIV/AIDS adalah antara 30\% - 60\%. Berbagai gangguan psikiatrik yang sering menyertai penyakit HIV/AIDS antara lain depresi, ansietas, post traumatic stress disorder (PTSD), dan lain-lain. Diagnosis yang paling banyak adalah depresi berat, kecemasan, dan gangguan penyesuaian, walaupun tidak ada bukti insidensi yang tinggi dari psikosis pada infeksi HIV. Depresi berhubungan dengan keadaan psikiatrik yang paling umum dengan infeksi HIV. Prevalensi gangguan depresi berat pada penderita dengan HIV positif adalah 2-3 kali lebih tinggi dari pada populasi umum. Penelitian lainnya yang diadakan pada klinik spesialis HIV pusat perawatan kesehatan tersier (Tentiary Health Care Centre) di India Selatan melaporkan 10\%- 40\% individu HIV positif menderita depresi. Di antara pasienpasien yang depresi $20 \%$ menunjukkan harapan untuk mati, dan $12 \%$ dilaporkan kadang-kadang memunculkan ide-ide suicide, sedangkan $8 \%$ melakukan percobaan hingga commit suicide. Penelitian meta analisis yang dipublikasikan Ciesa dan Roberts (Saragih, 2008) menemukan bahwa orang dengan HIV positif, kemungkinan hampir dua kali lebih banyak didiagnosa dengan depresi berat dan orang dengan HIV simtomatik dan asimtomatik umumnya adalah sama mengalami depresi.

Bastian dan Wawan (2003) mengutarakan ketika seseorang didiagnosis terinfeksi HIV/AIDS, maka hampir selalu ini merupakan pengalaman emosional yang tidak menyenangkan.Meskipun terkena karena perilaku mereka sendiri, diagnosa HIV bisa terasa berat untuk dapat diterima. Reaksi bisa beragam, ada yang bereaksi dengan kemarahan, ketakutan yang amat sangat, membantah kebenaran tes, atau kadang, dengan reaksi tumpul. Nasution (2004) dalam hasil penelitiannya memaparkan begitu terinfeksi AIDS, individu akan mengalami shock, bisa putus asa (karena shock berat) dan depresi berat. Hal ini menyebabkan penyakit makin lama makin berat, timbul berbagai infeksi 
opotunistik, penderita makin tersiksa. Biaya pengobatan tambah besar, macam penyakit tambah banyak, obat yang diberi harus tambah banyak dan tambah keras, dengan berbagai efek samping, yang memperparah keadaan penderita. Masyarakat sekitar turut pula memperburuk keadaan kejiwaan penderita, dengan segala macam isu dan ejekan yang dilontarkan (Widiyanto, 2009).

Depresi adalah suatu kondisi yang lebih dari suatu keadaan sedih. Bila kondisi depresi seseorang sampai menyebabkan terganggunya aktivitas sosial sehari-harinya maka hal itu disebut sebagai suatu gangguan depresi. Beberapa gejala gangguan depresi adalah perasaan sedih, rasa lelah yang berlebihan setelah aktivitas rutin yang biasa, hilang minat dan semangat, malas beraktivitas, dan gangguan pola tidur. Depresi merupakan salah satu penyebab utama kejadian bunuh diri.

Penyebab suatu kondisi depresi meliputi: Faktor organobiologis karena ketidakseimbangan neurotransmiter di otak terutama serotonin, faktor psikologis karena tekanan beban psikis, dampak pembelajaran perilaku terhadap suatu situasi sosial dan faktor sosio-lingkungan misalnya karena kehilangan pasangan hidup, kehilangan pekerjaan, paska bencana, dampak situasi kehidupan sehari-hari lainnya. Menurut Diagnostic and Statistical Manual IV - Text Revision atau DSM IV-TR (American Psychiatric Association, 2000), seseorang menderita gangguan depresi jika lima (atau lebih) gejala di bawah telah ada selama periode dua minggu dan merupakan perubahan dari keadaan biasa seseorang, sekurangnya salah satu gejala harus emosi depresi atau kehilangan minat atau kemampuan menikmati sesuatu, yaitu: (1) keadaan emosi depresi/tertekan sebagian besar waktu dalam satu hari, hampir setiap hari, yang ditandai oleh laporan subjektif (misal: rasa sedih atau hampa) atau pengamatan orang lain (misal: terlihat seperti ingin menangis), (2) kehilangan minat atau rasa nikmat terhadap semua, atau hampir semua kegiatan sebagian besar waktu dalam satu hari, hampir setiap hari (ditandai oleh laporan subjektif atau pengamatan orang lain), (3) hilangnya berat badan yang signifikan saat tidak melakukan diet atau bertambahnya berat badan secara signifikan (misal: perubahan berat badan lebih dari 5\% berat badan sebelumnya dalam satu bulan), (4) insomnia atau hipersomnia hampir setiap hari, (5) kegelisahan atau kelambatan psikomotor hampir setiap hari (dapat diamati oleh orang lain, bukan hanya perasaan subjektif akan kegelisahan atau merasa lambat), (6) perasaan lelah atau kehilangan kekuatan hampir setiap hari, (7) perasaan tidak berharga atau perasaan bersalah yang berlebihan atau tidak wajar (bisa merupakan delusi) hampir setiap hari, (8) berkurangnya kemampuan untuk berpikir atau berkonsentrasi, atau sulit membuat keputusan, hampir setiap hari (ditandai oleh laporan subjektif atau pengamatan orang lain), (9) berulang-kali muncul pikiran akan kematian (bukan hanya takut mati), berulang-kali muncul pikiran untuk bunuh diri tanpa rencana yang jelas, atau usaha bunuh diri atau rencana yang spesifik untuk mengakhiri nyawa sendiri.

Dari sembilan gejala yang dipaparkan di atas, ditemukan tujuh gejala depresi yang dialami subjek dalam penelitian ini. Hal ini terungkap pada saat peneliti melaksanakan pengambilan data. Pada saat itu subjek bercerita apa yang mereka alami pada saat mereka terinfeksi HIV/AIDS, yaitu rasa sedih terhadap diri sendiri, hilangnya minat dalam segala hal, berat badan yang berkurang derastis, susah tidur, merasa gelisah dalam kesehari-harian, merasa tidak berharga sehingga merasa bersalah akan keadaan yang subjek alami dan memunculkan pemikiran untuk mengkahiri masalah-masalah yang subjek alami (ideasi untuk bunuh diri). Gejala-gejala tersebut juga harus menyebabkan gangguan jiwa yang cukup besar dan signifikan sehingga menyebabkan gangguan nyata dalam kehidupan sosial, pekerjaan atau area penting dalam kehidupan seseorang.

Menurut Aditya (Suara Pembaruan, Kamis 4 juli 2002), yang terpenting dalam penanganan depresi ini adalah penguatan 
individu di sekeliling penderita HIV/AIDS, selain faktor aktif melakukan konseling dan menjalani hidup sehat agar bisa mempertahankan hidup lebih lama dari penyakit yang menggerogoti kekebalan tubuh ini. "Seringkali terjadi penyangkalan atau penolakan terhadap penderita oleh keluarganya, ketika sampai di rumah, bahkan terjadi pengasingan penderita sehingga membuat mereka lari dari rumah dan ini malah menambah mata rantai penularan HIV/AIDS," ujar aktivis dan konselor AIDS ini.

Dukungan keluarga yang dimaksud disini termasuk ke dalam dukungan sosial, karena dukungan kelurga termasuk dalam dukungan sosial. Dukungan keluarga termasuk hal yang paling dibutuhkan seseorang dalam upaya meningkatkan motivasi sehingga dapat mempengaruhi kesehatan individu dan dapat mengurangi depresi yang disebabkan rasa putus asa karena menderita penyakit HIV/AIDS. Dengan dukungan keluarga seseorang bukan hanya termotivasi untuk terus menempuh cara melanjutkan hidup tapi juga lahirnya perasaan nyaman dan tenang saat seseorang tersebut mengetahui dengan jelas bahwa keluarganya tidak menjauhinya, tidak acuh tak acuh terhadap dirinya dan mendukungnya dalam menjalani hidupnya atas penyakitnya. Dukungan keluarga bisa dimaknai juga sebagai suatu dorongan yang walau bagaimanapun tentu akan besar artinya bagi ODHA karena putus asa dengan penyakitnya.

Berdasarkan uraian di atas, maka pertanyaan pada penelitian ini adalah, apakah ada hubungan antara dukungan keluarga terhadap kecenderungan depresi pada penderita HIV/AIDS?. Untuk menjawab pertanyaan tersebut, penelitian ini menggunakan pendekatan kuantitatif dengan mempertimbangkan kemampuan pendekatan kuantitatif untuk mengukur reaksi sejumlah orang dalam suatu jumlah yang terbatas sehingga memudahkan dalam perbandingan dan pengumpulan data secara statistik, seperti yang dikemukakan oleh Patton (Tjala \& Baeda, 2001). Penelitian ini akan dilakukan kepada ODHA HIV/AIDS yang telah menderita HIV/AIDS selama 3 sampai 6 bulan dan minimal 15-60 tahun. Adapun hipotesis yang diajukan dalam penelitian ini adalah ada hubungan negatif antara dukungan keluarga dan kecenderungan depresi pada penderita HIV/AIDS.

\section{METODE PENELITIAN}

\section{Variabel Penelitian}

Penelitian ini mengungkap dukungan keluarga sebagai variabel bebas dan depresi sebagai variabel tergantung.

\section{Subjek Penelitian}

Subjek pada penelitian ini adalah penderita HIV/AIDS atau ODHA di DIY, berusia 15-60 tahun, berjenis kelamin lakilaki dan perempuan, berjumlah 50 orang. Dari data yang dihasilkan pada rentang usia 15-20 tahun tercatat sebanyak 1 subjek, pada usia 21-35 tahun tercatat 14 subjek, pada usia 35-50 tahun tercatat 29 subjek dan pada usia 50 tahun terdapat 6 subjek, dan dari data yang dicatat terdapat ada yang kurang dari 1 tahun mengidap HIV/AIDS tercatat 1 subjek, lebih dari 1 tahun tercatat sebanyak 37 subjek dan lebih dari 5 tahun tercatat sebanyak 12 subjek.

\section{Alat Ukur}

Penelitian mengenai Dukungan Keluarga dan Kecenderungan Depresi pada Penderita HIV AIDS, menggunakan BDI (Beck Depresision Inventory) sebagai alat ukur. Oleh karena itu, peneliti akan mengacu kepada aspek-aspek depresi menurut Beck. Semakin tinggi skor yang diperolah maka semakin tinggi depresi, dan semakin rendahnya skor yang diperoleh maka semakin rendah kecenderungan depresinya. Sedangkan alat ukur dalam mengukur dukungan keluarga di ungkapkan dengan mempergunakan Skala Dukungan Keluarga yang dibuat sendiri oleh peneliti. Tinggi ataupun rendahnya pemberian dukungan keluarga dapat dilihat pada skor yang diperoleh. Jika skor yang diperoleh tinggi, maka semakin tinggi pemberian dukungan 
keluarga, sebaliknya jika hasil skor skala rendah maka semakin rendah dukungan keluarga.

\section{Teknik Analisis}

Teknik analisis data yang dilakukan meliputi : uji validitas dan reliabilitas, uji normalitas, uji linieritas dan uji hipotesis. Untuk mempermudah proses perhitungan statistik, maka keseluruhan perhitungan dan pengujian hipotesis dalam penelitian ini dilakukan dengan menggunakan program komputer SPSS 16.0 for Windows dan menggunakan korelasi oleh Spearman.

\section{HASIL PENELITIAN}

\section{Uji Asumsi}

Sebelum melakukan analisis data penelitian, maka terlebih dahulu dilakukan uji prasyarat analisis, yaitu berupa uji asumsi yang meliputi uji normalitas dan uji linieritas sebagai syarat untuk pengetesan nilai korelasi agar kesimpulan yang diambil tidak menyimpang dari yang seharusnya. Uji asumsi dilakukan dengan menggunakan program SPSS 16,0 for windows.

\section{Uji Normalitas}

Uji normalitas bertujuan untuk melihat apakah bentuk distribusi atau sebaran dari skor jawaban subjek normal atau tidak. Pengujian normalitas dilakukan terhadap distribusi skor dukungan keluarga dan depresi, dengan menggunakan teknik one sample kolmogorov smirnov test. Standar yang digunakan untuk mengetahui normal atau tidaknya sebaran data adalah jika $p>$ 0.05 maka sebaran dinyatakan normal, namun jika $\mathrm{p}<0.05$ maka sebaran dinyatakan tidak normal.

Dari hasil pengolahan data depresi diperoleh koefisien $\mathrm{K}-\mathrm{SZ}=1.111$ dengan $\mathrm{p}=$ $0.169(\mathrm{p}>0.05)$ dan data dukungan keluarga diperoleh $\mathrm{K}-\mathrm{SZ}=2.058$ dengan $\mathrm{p}=0.00(\mathrm{p}<$ $0.05)$. Hasil uji normalitas tersebut menunjukkan bahwa data dukungan keluarga dapat dikatakan sebaran datanya tidak normal, sedangkan depresi sebaran datanya dikatakan terdistribusi dengan normal. Hasil tersebut dapat dilihat pada tabel di bawah ini:
Tabel 1. Tabel uji normalitas

\begin{tabular}{llll}
\hline Variable & KS-Z & $\mathbf{p}$ & Normalitas \\
\hline Dukungan Keluarga & 2.058 & 0.00 & Tidak Normal \\
Depresi & 1.111 & 0.169 & Normal \\
\hline
\end{tabular}

\section{Uji Linieritas}

Uji linieritas merupakan pengujian garis regresi antara variabel bebas dengan variabel tergantung. Uji ini bertujuan untuk mengetahui apakah hubungan antara variabel dukungan keluarga dengan depresi pada penderita HIV/AIDS di Yogyakarta mengikuti garis linier atau tidak. Kaidah yang digunakan untuk mengetahui apakah hubungan antara variabel mengikuti garis linier atau tidak, adalah jika $\mathrm{p}<0.05$ maka dikatakan hubungannya mengikuti garis linier dan sebaliknya, jika $\mathrm{p}>0.05$ maka hubungannya tidak mengikuti garis linier.

Dari hasil uji linearitas pada kedua variabel diperoleh $\mathrm{F}=12.065$ dengan $\mathrm{p}=$ $0.001 \quad(p<0.05)$, sehingga dapat dikatakan bahwa ada hubungan antara kedua variabel karena hasil yang diperoleh mengikuti garis linier. Dikarenakan data dukungan keluarga sebaran datanya tidak normal, maka data dalam penelitian ini dianalisis dengan menggunakan teknik product moment dari Spearman. Hal tersebut dapat dilihat pada tabel di bawah ini:

Tabel 2. Hasil uji Linieritas

\begin{tabular}{lccl}
\hline \multicolumn{1}{c}{ variabel } & $\mathbf{F}$ & $\mathbf{p}$ & Linieritas \\
\hline $\begin{array}{l}\text { Dukungan Keluarga } \\
\text { Depresi }\end{array}$ & 12.065 & 0.001 & Linier \\
\hline
\end{tabular}

\section{Uji Hipotesis}

Hipotesis yang diajukan dalam penelitian ini adalah adanya ada hubungan yang positif antara dukungan keluarga dan depresi pada penderita HIV/AIDS di Yogyakarta. Semakin tinggi dukungan keluarga maka semakin rendah depresi pada penderita HIV/AIDS, sebaliknya semakin rendah dukungan keluarga maka semakin tinggi depresi pada penderita HIV/AIDS di Yogyakarta.

Pengujian terhadap hipotesis tersebut menggunakan teknik korelasi Spearman. Dari hasil pengolahan data diperoleh koefisien korelasi $\mathrm{r}=-0.434$ dengan $\mathrm{p}=$ $0.001(p<0.05)$. Besarnya nilai $r=-0.434$ 
menunjukkan bahwa adanya korelasi negatif antar variable bebas dengan tergantung. Angka $\mathrm{p}=0.001<0.05$ menunjukkan bahwa ada hubungan negatif yang sangat signifikan antar variabel bebas dengan variabel tergantung. Besarnya $\mathrm{r}^{2}=0.189$ menunjukkan bahwa sumbangan dukungan keluarga terhadap depresi sebesar $18.9 \%$. Hasil uji hipotesis dapat dilihat pada tabel dibawah ini:

Tabel 3. Hasil Uji Hipotesis

\begin{tabular}{lllll}
\hline Variabel & $\mathrm{r}$ & $\boldsymbol{r}^{2}$ & $\mathrm{p}$ & Keterangan \\
\hline Dukungan Keluarga & -0.434 & 0.187 & 0.001 & Sangat Signifikan \\
Depresi & & & & \\
\hline
\end{tabular}

Hasil analisis data ini menunjukkan bahwa hipotesis yang dikemukakan di awal oleh peneliti diterima.

\section{PEMBAHASAN}

Penelitian ini bertujuan untuk mengetahui hubungan antara dukungan keluarga terhadap depresi pada penderita HIV/AIDS. Setelah melakukan penelitian, maka terbukti bahwa ada hubungan negatif yang signifikan antara dukungan keluarga dengan depresi pada penderita HIV/AIDS dan dapat diartikan bahwa semakin tinggi dukungan keluarga maka semakin rendah kecenderungan depresi pada penderita HIV/AIDS.

Jadi, upaya untuk mengatasi depresi yang ditimbulkan dari situasi di mana penderita harus menjalani hari-hari dengan penuh tekanan dan kebimbangan dalam menjalani hidupnya, maka dibutuhkan suatu cara yang tepat dan efektif. Salah satu caranya adalah pemberian dukungan keluarga. Dukungan keluarga ini berperan dalam mengurangi tingkat kecenderungan depresi pada saat terjadi tekanan pada penderita HIV/AIDS.

Sumber dukungan keluarga yang dapat mempengaruhi depresi bisa diperoleh dari dukungan secara emosional. Dukungan ini melibatkan perhatian yang berhubungan dengan emosi yang diberikan pada orang lain. Dukungan emosianal mencakup empati, kepedulian dan perhatian yang diberikan kepada ODHA dari orang-orang di sekitarnya terutama anggota keluarganya. Jika dukungan ini dirasakan oleh ODHA, maka ia akan memberikan kenyamanan dan perasaan saling memiliki dan dicintai ketika ODHA dalam keadaan tertekan, sehingga dapat menghindarkan ODHA dari depresi.

Dukungan penghargaan, dukungan ini terjadi lewat ungkapan hormat atau penghargaan positif untuk ODHA, dorongan maju atau persetujuan dengan gagasan atau perasaan individu dan perbandingan antara orang lain dan dirinya sehingga bisa menambah penghargaan diri individu. Selain itu dukungan penghargaan dapat membangun harga diri individu dengan sangat efektif saat individu berada pada situasi yang menekan. Jika dukungan ini diterima ODHA tentu saja akan memberikan dampak yang positif pada ODHA.

Dukungan instrumental mencakup bantuan langsung kepada ODHA, seperti jika orang lain memberikan bantuan pada saat individu sangat membutuhkan bantuan, sehingga di mana pada saat ODHA membutuhkan bantuan dan orang-orang disekitarnya terutama anggota keluarganya dapat langsung memberikan bantuan, sehingga ODHA merasa diperhatikan oleh keluarganya dan tentu saja. Jika dukungan instrumental dapat terpenuhi, maka depresi yang akan terjadi pada ODHA dapat terhindari.

Dukungan informatif merupakan hal yang biasa-biasa saja akan tetapi apabila dukungan ini diberikan kepada orang yang membutuhkannya akan berdampak sangat besar dan menjadi hal yang positif. Dukungan ini mencakup pemberian nasehat, petunjuk-petunjuk, saran atau umpan balik. Jika ODHA mendapatkan dukungan ini, maka akan menghindarkan ODHA dari depresi. Namun, jika ODHA tidak mendapatkan dukungan ini maka akan mempercepat kecenderungan depresi yang akan dialami ODHA, karena ODHA akan merasa bahwa dirinya tidak diperdulikan oleh orang-orang di sekitarnya dan terutama anggota keluarganya. Jadi apabila dukungandukungan ini diberikan oleh orang-orang terdekat ODHA, terutama keluarganya, maka akan berdampak positif dalam membangun kepercayaan diri, harga diri, dan tentu saja kesehatan secara fisik ataupun mental. Dari penjelasan di atas dapat ditarik 
secara garis besar bahwa dukungan keluarga menjadi salah satu senjata untuk melawan depresi pada penderita HIV/AIDS. Mereka dapat memperoleh lagi penghargaan diri mereka karena kekuatan dan jaringan hubungan dengan orang lain sehingga dapat membantu penderita HIV/AIDS untuk menyadari bahwa mereka merasa dihargai serta memiliki keyakinan kembali setelah kehilangan kepercayaan diri (Cohan dan Hoberman, 1996)

Hasil analisis data yang dilakukan, menunjukkan nilai koefisien korelasi $\mathrm{r}=$ 0.434 dan $p=0.001(p<0,05)$ yang artinya terdapat hubungan yang signifikan antara dukungan keluarga terhadap depresi pada penderita HIV/AIDS dan dukungan keluarga juga memberikan sumbangan efektif sebesar 18.9\% kepada depresi pada penderita HIV/AIDS. Sisanya yaitu sebesar $81.1 \%$ dipengaruhi oleh faktor-faktor yang lain, yang berasal dari luar variabel yang diteliti dalam penelitian ini.

Pada kategorisasi dukungan keluarga subjek penelitian menunjukkan kategori sedang mengarah pada angka $74 \%$, sehingga dapat disimpulkan bahwa dukungan keluarga yang dimiliki oleh penderita HIV/AIDS berada dalam kategori sedang, sehingga semakin tinggi dukungan keluarga maka semakin rendah kecenderungan depresi pada subjek di penelitian ini. Pada kategorisasi depresi subjek penelitian tergolong sangat rendah dan ringan mengarah pada angka $48 \%$, jadi dapat ditarik sebuah simpulan bahwa pada sebagian besar penderita HIV/AIDS mengalami depresi dalam tingkatan yang sangat rendah dan ringan. Jadi semakin rendah depresi yang dimiliki subjek, maka semakin tinggi dukungan keluarga pada subjek di penelitian ini.

Kondisi ini dijelaskan oleh Sarafino (2006) bahwa berinteraksi dengan orang lain dapat memodifikasi atau mengubah persepsi individu mengenai kejadian tersebut, dan ini akan mengurangi potensi munculnya stres baru atau stres yang berkepanjangan sehingga menimbulkan perasaan depresi. Depresi muncul ketika upaya negosiasi tidak menolong dan orang tersebut merasa sudah tidak ada waktu untuk peluang lagi serta tidak berdaya.

Dukungan keluarga yang diterima subjek ternyata berdampak positif terhadap aspek kesehatan, psikologis, sosial dan pekerjaan. Berikut ini adalah dampak yang diperoleh subjek, yaitu dampak keluarga terhadap psikologis bisa kita pahami dengan adanya dukungan keluarga yang subjek peroleh, menjadikan subjek tetap percaya diri dalam berhubungan dengan orang lain, tidak merasa rendah diri, tidak mudah putus asa, tidak minder, merasa dirinya berarti, tidak merasa cemas, tetap bersemangat, merasa ikhlas dengan kondisi subjek saat ini dan merasa lebih tenang dalam menghadapi sesuatu masalah.

Dampak dukungan keluarga terhadap kesehatan subjek yaitu, stres yang tinggi dan berlangsung dalam jangka waktu yang panjang atau lama dapat menimbulkan depresi dan memperburuk kondisi kesehatan dan menyebabkan penyakit. Tetapi dengan adanya dukungan keluarga yang diterima oleh individu yang sedang mengalami atau menghadapi depresi maka hal ini akan dapat mempertahankan daya tahan tubuh dan meningkatkan kesehatan individu (Baron \& Byrne, 2000). Hal ini sesuai dengan yang dialami subjek, jika dilihat dari kondisi subjek yang terpapar HIV dan melemahnya sistem kekebalan tubuh subjek, maka tubuh subjek rentan terhadap penyakit. Adanya dukungan psikologis yang positif terhadap diri subjek menjadikan subjek terhindar dari stres. Hal tersebut memberikan dampak positif terhadap kesehatan subjek, sehingga subjek merasa lebih sehat, tidak mudah lelah dan tidak mudah sakit. Selain itu pun, dalam memerangi virus HIV, subjek menjadi lebih menjaga kesehatanya dengan minum obat secara teratur, makan tepat waktu, selalu berusaha menghindari pemakaian obatobatan terlarang dan secara rutin mengkonsultasikan masalah kesehatannya ke dokter.

Dampak dukungan keluarga terhadap lingkungan sosial, yaitu dengan adanya dukungan sosial dan keluarga yang subjek peroleh, menjadikan subjek dapat bersosialisasi dengan lingkungan sekitar. Karena subjek memiliki banyak teman, 
subjek dapat membantu dalam memberikan informasi mengenai akses kesehatan dan informasi tentang HIV/AIDS pada teman kelompok dukungan serta kepada masyarakat sekitar.

Dampak dukungan keluarga terhadap pekerjaan dapat dilihat dari pekerjaan subjek, saat ini subjek bekerja disebuah LSM yang menangani masalah HIV/AIDS. Adanya dukungan yang diperoleh subjek menjadikan subjek dapat mengoptimalkan keterampilan yang ada di dalam diri subjek dalam melakukan suatu pekerjaan, menjadikan subjek menjadi kreatif serta subjek dapat mengevaluasi pekerjaan subjek sehingga dapat menghasilkan pekerjaan yang lebih baik. Hal ini sesuai dengan hasil penelitian (Kandouw, 2007) yang menyatakan masalah psikologis yang paling sering adalah depresi dan berbagai masalah sosial seperti stigma, masalah perkawinan, pekerjaan, dan lainlain dimana dukungan keluarga akan mempengaruhi keadaan tersebut.

Hasil penelitian yang sudah didapat menujukkan dukungan keluarga memberikan dampak yang positif dalam kehidupan diri subjek, di dalam penelitian ini dan memungkinkan dari sumbangan dukungan keluarga terhadap depresi sebesar $18.9 \%$. Selebihnya sebanyak $81.1 \%$ bisa disebabkan dari faktor-faktor yang subjek dapatkan di dalam kehidupannya. Namun subjek dalam penelitian ini tertutup terhadap keadaannya sehingga peneliti menggunakan metode kuantitatif dengan skala sebagai alat ukur dalam penelitian ini dan pada saat pelaksanaan pengambilan data peneliti hanya dapat bertemu langsung kepada subjek hanya beberapa orang dikarenakan keadaan subjek yang tertutup, peneliti menggunakan jasa konselor yang sudah dipercaya oleh subjek, seharusnya lebih baik peneliti yang melakukan pengambilan data dikarenakan ada persamaan persepsi terhadap alat ukur yang digunakan pada penelitian ini. Pembuatan aitem-aitem yang digunakan pada skala dukungan keluarga belum spesifik mengungkapkan tentang dukungan keluarga, maka perlu dikhususkan lagi sumber dukungan keluarganya, sehingga subjek dapat memahami apa yang dimaksud dengan sumber dukungan keluarga pada skala dukungan keluarga yang menjadi tolak ukur dalam penelitian ini.

\section{SIMPULAN DAN SRAN}

\section{Simpulan}

Simpulan yang dapat diambil dari penelitian ini adalah terdapat korelasi yang negatif yang sangat signifikan antara dukungan keluarga dengan depresi dengan nilai $\mathrm{p}=0.001(\mathrm{p}<0.05)$ dan nilai $\mathrm{r}=-0.434$. Hal ini menunjukkan bahwa semakin tinggi dukungan keluarga maka akan semakin rendah depresi. Begitu pula sebaliknya, semakin rendah dukungan keluarga maka akan semakin tinggi depresi. Implikasi hasil penelitian ini memberikan pemahaman akan pentingnya memberi dukungan dari orang terdekat khususnya keluarga bagi para penderita HIV/AIDS karena apa yang mereka alami di dalam kehidupannya rentan mengalami depresi.

\section{Saran}

1. Bagi Pihak Keluarga ODHA

Berdasarkan hasil penelitian, kepada pihak keluarga dari ODHA disarankan untuk selalu memberikan dukungan baik secara moral atau fisik karena dengan diberikannya perhatian yang lebih kepada ODHA akan memberikan dampak positif untuk kehidupan ODHA.

Bagi peneliti selanjutnya

Peneliti menemukan kelemahan dari penelitian ini. Berikut beberapa saran yang dapat dilakukan oleh peneliti selanjutnya guna meningkatkan kualitas penelitian. Aitem dibuat lebih sedikit dengan tingkat validitas yang lebih tinggi. Hal ini untuk menghindari kelelahan subjek dalam ketika mengerjakan skala. Disarankan pengambilan data dalam penelitian langsung peneliti sendiri yang melaksanakannya dikarenakan dalam pelaksanaan pengisian skala dukungan keluarga dan depresi antara subjek dan peneliti perlu adanya kesamaan persepsi sehingga subjek mengerti apa yang seharusnya subjek berikan dalam penelitian ini. 


\section{DAFTAR PUSTAKA}

Beck, A.T. (1985). Depression : Causes and Treatment. Philadelphia: University of Pennsylvania Press

Baron, R.A., \& Byrne, D. (2000). Social psychology, $9^{\text {th }}$ ed. Boston: Allyn \& Bacon.

Saragih, J (2008). Sindrom Depresif Pada Penderita HIV/AIDS Di RSUP Haji Adam Malik Medan. Skripsi (Tidak diterbitkan). Medan: USU.

Kandouw, A. (2007). Proporsi gangguan Depresi Pada penyalahgunaan Zat yang Menjalani Rehabilitasi di RS Marzoeki Mahdi. No 156. Jakarta :Jurnal Cermin Dunia Kedokteran.
Sarafino, E.P. (1994). Biopsychosocial Interactions. Health Psychology Journal. New York John Wiley \& Sons, Inc:

Sarafino, E.P. (2006). Biopsychosocial Interactions. Health Psychology $5^{\text {th }}$ Edition. New York John Wiley \& Sons, Inc :

Tjala, A.,\& Baeda, N. (2001). Penajaman Hasil Penelitian Psikologi dengan Pendekatan Kuantitatif. Jurnal Ilmiah Psikologi Arkhe. Th 6/no.1/2001

Widiyanto, W. (2009). Strategi koping penderita hiv/aids. Skripsi (Tidak diterbitkan). Surakarta : Fakultas Psikologi UMS. 